\title{
Investigation of the Healing Effects of Afyonkarahisar Region Hot Spring Waters' Inhalation on Experimentally Induced Asthma in Mice
}

\section{ELITOK Bülent ${ }^{1}$, ULUSOY Yavuz ${ }^{2}$, KİLINC Bahadir ${ }^{2}$}

1. Afyon Kocatepe University, Faculty of Veterinary Medicine, 2. Ministry of Agriculture and Forestry, Veterinary Control Central Research Institute, Pathology Laboratory, Ankara/ Turkey Corresponding author: ELITOK Bülent, Email: elitok1969@hotmail.com

ORCID: https:/ /orcid. org/ 0000-0003-3336-4479

\begin{abstract}
Asthma is a chronic inflammatory disease of the airways observed exclusively in humans and sometimes animals. In this study, 40 Albino rats of the same age were used. After 6 weeks of ovalbumin-induced asthma in all animals, 40 rats were randomly divided into two groups as control and study groups for a 21-day treatment period. At the treatment stage, the control group animals were treated with normal tap water, while the study group animals were treated with hot spring water. Clinical, hematological, blood biochemical and histopathological examinations were performed before starting the study, after asthma formation, and on days of 1st, 7th, 14th and 21st after treatment. Total leukocyte, neutrophil, monocyte, AST, ALT, GGT, total cholesterol, triglyceride levels were significantly decreased $(\mathrm{p}<0.05)$ in the study group animals which treated with hot spring water. These normalization changes were confirmed by histopathological findings. Consequently, it was concluded that hot spring water of Afyonkarahisar Region provide a very successful treatment in asthma, and it should be considered as a supportive option for the treatment of asthma.
\end{abstract}

Key words: Asthma, balneotherapy, biochemistry, hematology, histopathology,

\section{Introduction}

Asthma is a chronic inflammatory disease of the airways in which a large number of inflammatory cells play a role and the disease is a complex syndrome observed exclusively in humans (1). In animals, asthma-like conditions are observed in cats with eosinophilic bronchitis and in equines with heaves (2). Many animal species have been used to study the mechanisms involved in asthma (Drosophila, rat, guinea pig, cat, dog, swine, cattle, sheep, horse and primates), but the most common model is the murine allergic airway inflammation (3).

Asthma charcterized by symptoms such as narrowing of the respiratory tract and recurrent wheezing, shortness of breath and cough (4). While the symptoms of asthma can be reversible spontaneously or with appropriate treatment (5), there may also be some partially irreversible changes in the airways caused by inflammation, called remodeling (6).

First step in treatment is that the individual is away from the allergens to which is sensitive, whereas the second step of the treatment involves the use of therapeutic agents. Therapy with hot spring mineral waters in inhalation style has been reported to contribute significantly to clinical recovery of asthma as well as many respiratory diseases (7-10).

The purpose of this study was to present the efficacy of the treatment with scientific data in asthmatic mice which treated with the rich content of Süreyya I hot spring water where located in Afyonkarahisar Province.

\section{Materials and Methods}

The experimental part of this study was conducted in Afyon Kocatepe University Experimental Animals Application and Research Center, in accordance with the Directive of Afyon Kocatepe University Experimental Animals Ethical Committee (AKUHADYEK) and was referred to with the report numbered 57-18, and Afyon Kocatepe University Scientific Research Projects Board (AKÜBAPK) was supported by the Research Project numbered 18.SAĞ.BİL.15.

\section{Animal Material}

In this study, a total of 40 Albino mice of the same daily age were used. The animals were were kept in a stable environment with equal humidity and temperature conditions, 12 hours night and 12 hours day, in this center. During the study, animals were provided to receive ad libitum mouse food. 


\section{Method}

\section{Experimental Asthma Formation Procedure}

Before applying the asthma procedure, 4 out of 40 mice were exed for collecting blood samples. Then, $20 \mu \mathrm{g}$ ovalbumin (OVA) (Sigma-Aldrich, St. Louis, MO, USA) + $1 \mathrm{mg}$ aluminum hydroxide (AlumThermo Scientific, Surrey, UK) solved in $500 \mu \mathrm{l}$ saline solution, and were made sensitive to asthma by applying intraperitoneally (ip) on days 0 and 10 . After the this step, the mice were inhaled from a $1 \%$ OVA solution with a spraying property of $<4 \mu$ in diameter for 6 weeks, 3 days a week for 30 minutes (11-13). After completing the asthma procedure, 36 mice were divided into 2 groups for the 21-day treatment period as follows:

1. Control Group (KG): Totally, 16 mice served as CG. The tap water was inhaled for 21 days in the morning and evening, twice a day for 20 minutes, by taking it into the devices specially prepared for the mice in CG. In addition, normal tap water was placed in the waterers of these mice and provided to reach the refreshed water and food ad libitum.

2. Study Group (SG): The remaining 16 mice assigned as SG. Fresh Süreyya I hot spring water was inhaled for 21 days in the morning and evening, twice a day for 20 minutes, by taking it into the devices specially prepared for the mice in SG. In addition, hot spring water was placed in the waterers of these mice and provided to reach the refreshed water and food ad libitum (Figure 1).

After the formation of asthma, treatment started. Four animals from each group were euthanized under ketamine $(100 \mathrm{mg} / \mathrm{kg}) / x y l a z i n e ~(10 \mathrm{mg} / \mathrm{kg})$ anesthesia and blood nd lung samples were taken for histopathological evaluations $(14,15)$. Tissue samples were stored at $10 \%$ formol and $+4{ }^{\circ} \mathrm{C}$, and sent to the Etlik Veterinary Research and Application Institute Pathology Laboratory for histopathological examinations.

Süreyya I Hot Spring Water used for the purpose of treatment in this study; It has a total mineral content of $4046.8 \mathrm{~g} / \mathrm{L}$ and is in the thermomineral water group with sodium bicarbonate, carbon dioxide, calcium, magnesium, fluoride and silicon.

\section{Clinical Examinations}

Body temperatures $(\mathrm{T})$, respiration $(\mathrm{R})$ and heart frequencies $(\mathrm{P})$ of the animals were measured in all the animals, and the data were recorded for statistical comparisons.

\section{Hematological Examinations}

Histopathological tissue samples were coincided with the time of collection and in blood samples taken from EDTA blood tubes directly from the hearts of the animals under anesthesia; erythrocyte (RBC), total leukocyte (WBC), hematocrit (HCT), hemoglobin (HB), mean corpusculer volume (MCV), mean corpusculer hemoglobin (MHC), mean corpusculer hemoglobin concentration (MCHC), lymphocyte (LENF), neutrophil (Hematological examinations such as NOTR), eosinophil (EOS), monocyte (MON) and basophil (BASE) were measured using Chemray Brand blood count device using commercial test kits.

\section{Blood Biochemical Examinations}

Serum aspartate aminotransferase (AST), serum lactate dehydrogenase (LDH), gamma-lutamil transefrase (GGT), alkaline phosphatase (ALP), total protein (TP), albumin (ALB), blood urea nitrogen (BUN), glucose (GLU) and total cholesterol (TCHOL) level measurements were made on the Cobas Integra 400 Plus Roche Brand (Roche Diagnostics $\mathrm{GmbH}$, Germany) analyzer. Immun globulin E (IgE) level measurements were measured using Chmewell Elisa Reader (ChemWell Chromate 4300 Elisa Reader, Awareness Technology, Inc. Martin Hwy. Palm City, USA) Elisa kits (Sunred Biological Technology Company Co. Shangai/China).

\section{Histopathology Examinations}

From the lung samples which were sent to the laboratory in $10 \%$ formol for histopathological examination, 5 micron thick sections were taken in the laboratory, the sections were stained with hematoxylin-eosin and examined histopathologically in the light microscope.

\section{Statistical Analysis}

Statistical calculations of the groups were made according to the variance analysis (ANOVA) method. Duncan test was used to reveal the importance of intra-group differences in the study group. Statistical analyzes were made using Windows compatible SPSS 18.1 (Inc., Chicago, II, USA) package program. Data were given as mean \pm standard error and $\mathrm{p}<0.05$ was considered as important.

\section{Results}

Before starting the study, the mean body weight (bw) of the animals was measured as $29.7 \mathrm{~g}$ (min.25.6- max.31.8), while the animals bw after asthma formation was determined as $29.1 \mathrm{~g}$ (min.25.8- max.32.1) ( $\mathrm{p}>0.05$ ). In measuremnts made on the 21 st day after treatment; CG mice bw average was $29.5 \mathrm{~g}$, while that of SG animal was measured as $28.2 \mathrm{~g}$. It was observed that there was a 
statistically significant difference between the groups in terms of their bw mean $(\mathrm{p}<0.05)$.

\section{Clinical Findings}

The clinical findings of the control and study groups are shown in Table 1 below. When Table 1 is examined; it was seen there was no significant difference in terms of $T$ averages $(p>0.05)$, whereas in terms of $\mathrm{T}, \mathrm{P}$ and $\mathrm{R}, \mathrm{CG}$ and $\mathrm{SG}$ shown significant differences $(p<0.05)$, and the most important changes occurred in SG animals on day of 21 st of the study $(\mathrm{p}<0.05)$.

\section{Hematological Findings}

Hematological findings are shown in Table 2. When this table is examined; WBC, NOTR, MON, EOS, BAS, HG, $\mathrm{MCH}$ and $\mathrm{MCHC}$ levels increased statistically significantly $(\mathrm{p}<0.05)$ after asthma formation, whereas RBC, HCT, LENF, PLT and MCV levels were significantly low $(p<0.05)$. When the averages of both groups were compared in terms of the measurements made in all time periods; levels for WBC, NOTR, MON, EOS, BAS, HG, MCH and MCHC were decreased, while levels for RBC, HCT, LENF and PLT were increased following treatment period. However, most significant $(p<0.05)$ changes were observed in SG on the 21st day.

\section{Blood Biochemical Findings}

The results of blood biochemical analyses are shown in Table 3. When Table 3 is examined; AST, LDH, GGT, ALP, BUN, CREA, TCHOL and IgE levels were increased $(p<0.05)$ and ALB levels were significantly decreased $(\mathrm{p}<0.05)$ when compared to the pre-study measurements.. On the contrary, following treatment period, ALB levels statistically significant $(\mathrm{p}<0.05)$ increased, whereas AST, LDH, GGT, ALP, BUN, CREA, TCHOL and IgE levels decreased in both group. However, most significant changes in terms of these parameters were found in SG animals on the 21 st day of the study.

\section{Histopathological Findings}

Acute catarrhal pneumonia, alveoli and bronchus were detected and the formation of asthma was confirmed by mononuclear cell infiltration. However, it has been observed that in animals with asthma, alveolar structures are lost and acute catarrhal pneumonia characterized by mononuclear cell infiltration (Figure 1). With the onset of the treatment period, unlike $C G$, it was found that the histopathological improvements gradually developed in SG mice (Figure 2). Pneumonia table characterized by mononuclear cell infiltrations still continued in CG group in the end of the study (Figure 3).

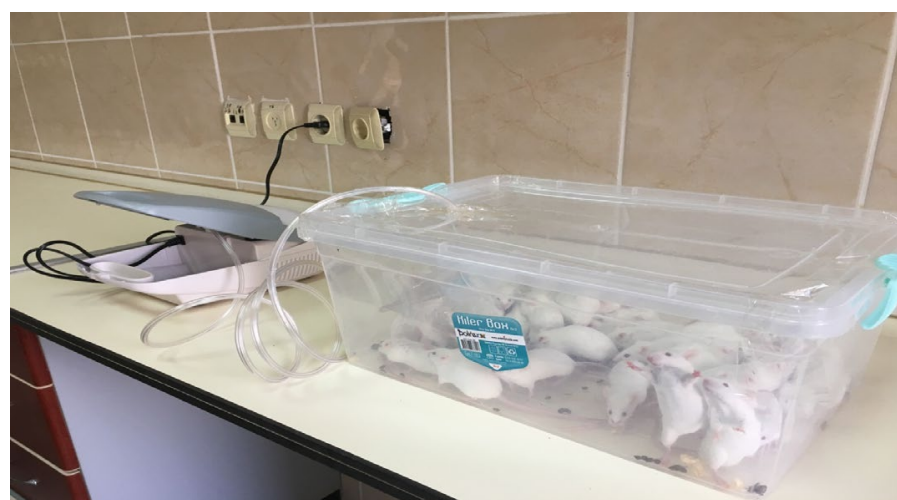

Figure 1. Application of water vapor

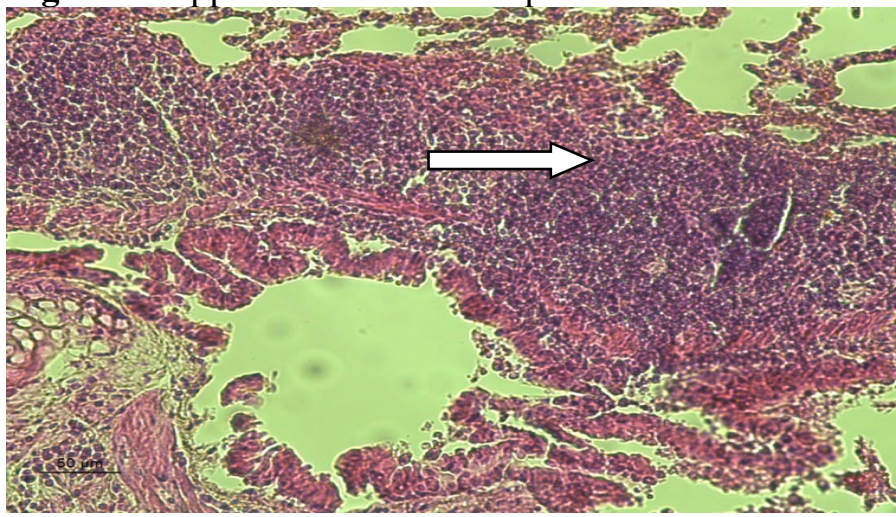

Figure 2. 10x20 HXE Painting. Lungs. Mononuclear cell infiltration in acute catarrhal pneumonia, alveoli and bronchi. Disease formation (White arrow). After asthma formaton.

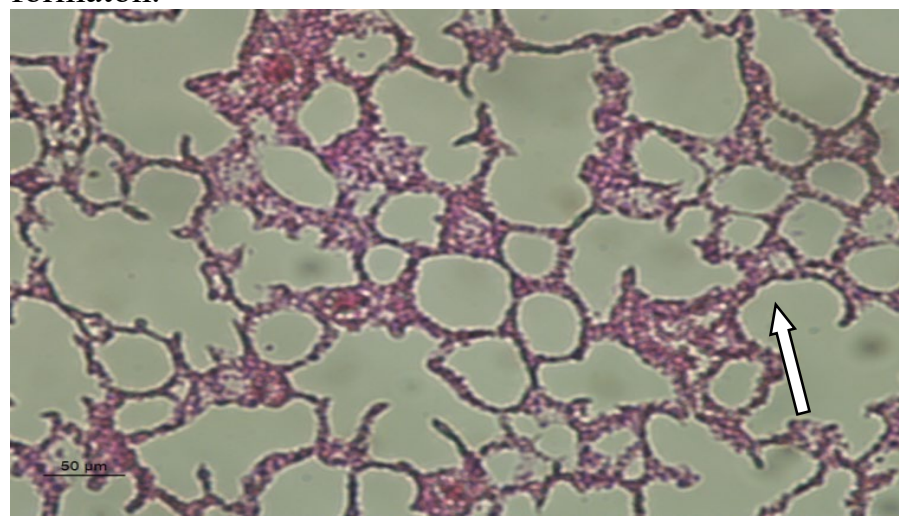

Figure 3. 10x20 HXE Painting. Lungs. Interalveolar septa are normal. (White arrow). Study group 21 th Day

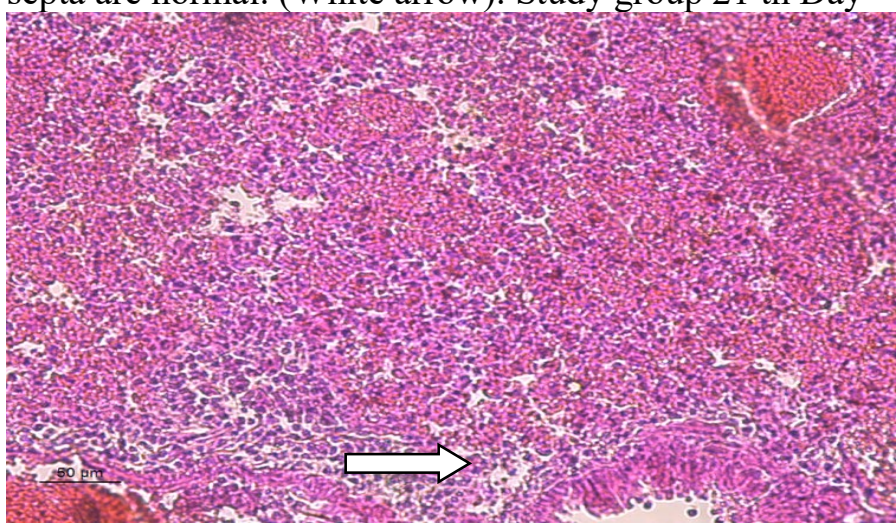

Figure 4. 10x20 HXE Painting. Lungs. Healing was not observed. Interalveolar septa disappeared. Table of pneumonia characterized by mononuclear cell infiltrations. Control group 21 th Day 


\section{Discussion}

Although Asthma observed exclusively in humans and sometimes animals, we can not reach any literatures which directly related to balneothrapy in asthma. Therefore, as far as we know, this study will be at first in this area.

It was determined that the mean bw of $\mathrm{CG}$ animals was higher than the mean of SG mice, and this difference was statistically significant $(\mathrm{p}<0.05)$. This finding shows that treatment with spa waters has a metabolic accelerating effect, by increasing fat burning and decreasing intestinal fat intake (16). It was found to be compatible with studies reporting that it caused loss $(17,18)$. It was observed that there was no statistically significant difference $(p>0.05)$ between the groups in terms of body temperatures in animals with asthma, whereas respiratory and heart frequencies increased statistically significantly ( $p$ $<0.05$ ) when compared to pre-study. These findings found compatible with the findings previously reported by some researchers $(19,20)$ who know that balneotherapy increases cardiac output, causes vasodilation in peripheral vessels, and causes an increase in the frequency of heart and accordingly, and the sympathetic nerve of hot baths. our findings were also found to be compatible with findings reported by the researchers $(21,22)$ who reported that they stimulated the system and caused increases in blood pressure, heart and respiratory frequency.

In our study, the RBC and HB averages were higher in SG than CG. Similarly, some researchers $(23,24)$ reported that asthma significantly decreased arterial oxygen tension and the study reporting that hot spring waters had a positive effect on the red blood cell index.

In our current study, the high levels of NOTR and WBC that we detected after the occurrence of asthma were consistent with the increased neutrophil and leukocyte content study observed in the airways and sputum of asthma patients during smoking and acute exacerbations (25). Following the asthma formation, there was a statistically significant ( $p$ $<0.05$ ) increase in WBC, LENF and EOS levels when compared to pre-study. On the other hands, SG animals which drinking, bathing and inhalating Süreyya I hot spring water statistically significant ( $p$ $<0.05$ ) have low levels of them. Some researchers $(17,26)$ have shown that hyperthermal waters $\left(<40^{\circ} \mathrm{C}\right)$ have an immunosuppressive effect and $\mathrm{T}$ lymphocytes in the blood significantly decrease in hyperthermal baths, provoking the ACTH hormone level and cortisol production in hyperthermal waters, and causes lymphocytopenia and eosinopenia.

Plasma ALB shows positive correlation with lung function (24). It has been reported that decreased total protein, globulin and ALB levels are observed in the serum of asthma patients (27). ALB is known as the most important extracellular antioxidant that regulates glutathione levels in the epithelial cells of the lungs (28). The antioxidant defense mechanism is associated with the pathogenesis of asthma because oxidant marker levels increase in asthma patients, whereas some antioxidants levels, including uric acid, ALB and bilirubin, decrease (29). However, in this study, higher creatinine, urea and BUN levels were observed in asthma patients when compared to the pre-study. This situation was compatible with the study (30) which reporting that kidney damage might occur in asthma patients.

It has been reported that there is no statistically significant change in alkaline phosphatase (ALP) levels in patients with asthma, although a statistically significant decrease in serum AST and ALT levels $(\mathrm{p}<0.05)$ is observed (24). In our current study, it was also found that significant increases in these enzyme levels sfollowing asthma formation. These findings we found were also consistent with the findings of researchers (31), who reported that these enzymes could rise to very high levels as a result of impaired pulmonary ventilation functions in asthmatic patients.

Although it is not yet understood how cholesterol plays a role in the inflammation and pathogenesis of asthma, it is generally accepted that dyslipidemia is one of the factors contributing to the pathogenesis of asthma (1). As a matter of fact, the prevalence of asthma was reported to be higher in children with high cholesterol and triglyceride levels in their serum (32). In our study, it was found that TG, LDL, TCHOL levels were significantly increased, but HDL cholesterol levels decreased following asthma formation. In contrast, with the start of the treatment period; compared with $\mathrm{CG}$, it was found that $\mathrm{SG}$ treated with hot spring water and steam had a reverse course in this lipid profile and best results were obtained in the last week in SG. These results obtained from our study were also in full agreement with the findings of the researchers $(33,34)$, who reported that the use of mineral waters with acute or chronic natural effects on the serum lipid profile.

In addition, it has been reported that $\mathrm{Mg}$ and $\mathrm{Ca}$, which are abundant in the Sureyya I hot spring water, can reduce the fat rate of individuals with 
lipid accumulation (35). However, it shows that $\mathrm{Mg}$ and $\mathrm{Ca}$ are not only effective in lowering fats, but other elements contribute to this (36). $\mathrm{HCO}_{3}$ comes first among these elements and it has been reported that water with rich $\mathrm{HCO}_{3}$ has a reducing effect on total and LDL cholesterol 33,37). Sureyya I hot spring water, which we use for the purpose of treatment in our study, is also a rich bicarbonate hot spring water and is a water with a very high $\mathrm{HCO}_{3}$ concentration.

Like dyslipidemias, glucose intolerance is an important risk factor for asthma (38). Spa treatments have been reported to regulate cases leading to impaired glucose tolerance with high blood sugar (39). In the current study, the decrease of high GLU levels in the animals with asthma after treatment in SG animals proves this effect of spa treatment.

In our study, it was found that the levels of $\operatorname{IgE}$ we measured showed statistically significant $(p<0.05)$ increases after asthma formation. Similar findings have been reported in many studies on asthma (24). In our study; the reduction of IgE levels in SG animals at the end of the treatment was an important finding in terms of the success of the treatment.

Histopathological tissue examinations on the last day of the study shown that unlike CG, histopathological improvementsdeveloped in $\mathrm{SG}$ mice. Since we couldn't find any literature to discuss about it, our finding will be the fisrt study about healing effects of balneotherapy in histopathological examinations.

\section{Conclusion}

Consequently; the clinical, hematological, blood biochemical parameters and histopathological examination findings obtained from the study in mice with asthma were evaluated as a whole; it had been revealed that treatment with Süreyya I hot spring water was very successful in asthma.

\section{Declaration of conflict of interests/Conflict of Interest Statement}

The authors declare that there is no conflict of interest regarding the publication of this article.

\section{Informed consent}

Informed consent was obtained from all patients included in this study.

\section{Acknowledgement}

Special thanks to Mr. Suayp Demirel for his supporting during study.

\section{References}

1. Cohn L, Elias JA, Chupp GL. Asthma: mechanisms of disease persistence and progression. Annu Rev Immunol. 2004; 22:789- 815.
2. Herszberg B, Ramos-Barbón D, Tamaoka M, Martin JG, Lavoie JP. Heaves, an asthma-like equine disease, involves airway smooth muscle remodeling. J Allergy Clin Immunol. 2006; 118(2):382-388.

3. Blume C, Davies DE. In vitro and ex vivo models of human asthma. Eur J Pharm Biopharm. 2013; 84(2):394-400.

4. Asher MI, Montefort S, Bjorksten B, Lai CK, Strachan DP. et al. ISAAC Phase Three Study Group. Worldwide time trends in the prevalence of symptoms of asthma, allergic rhinoconjunctivitis, and eczema in childhood: ISAAC Phases One and Three repeat multicountry cross-sectional surveys. Lancet. 2006; 368(9537):733-43.

5. Uysal P. Deneysel kronik astım modelinde farklı dozlarda verilen inhale steroidin akciğer ve kemik histopatolojisi üzerine etkisi. Yandal Uzmanlık Tezi. Dokuz Eylül Üniversitesi Tıp Fakültesi Çocuk Sağlığı ve Hastalıkları Anabilim Dalı, İzmir, 2012.

6. James A. Airway remodeling in asthma. Curr Opin Pulm Med. 2005; 11:1-6.

7. Yamaoka K, Mitsunobu F, Hanamoto K, Shibuya $\mathrm{K}$, Mori S. et al. Biochemical comparison between radon effects and thermal effects on humans in radon hot spring therapy. J Radiat Res. 2004; 45(1): 83-8.

8. Passali D, Gabelli G, Passali GC, Mosges $\mathrm{R}$, Bellussi LM. Radon-enriched hot spring water therapy for upper and lower respiratory tract inflammation. Otolaryngol Pol. 2017; 71(4): 8-13.

9. Etani R, Kataoka T, Kanzaki K, Sakoda A, Tanaka, H. et alProtective effects of hot spring water drinking and radon inhalation on ethanol-induced gastric mucosal injury in mice, Journal of Radiation Research. 2017; 58(5): 614-625.

10. Elitok B. Kaplicaların Mineral Mucizesi. Hancioğlu Ofset, Afyonkarahisar, 2011.

11. Delaney JCGR, Tian J, Oettgen H, Coyle AJ. Resolution of Bronchial Hyperresponsiveness and Pulmonary Inflammation Is Associated with IL-3 and Tissue Leukocyte Apoptosis J Immunol. 2001; 166:2033-2040.

12. Kumar RK, Herbert C, Foster PS. The 'classical' ovalbumin challenge model of asthma in mice. Curr. Drug Targets. 2008; 9: 485-494.

13. Yang YS, Yang MJ, Cho KH, Lee K, Kim YB. et al. Study of a BALB/c Mouse Model for Allergic Asthma. Toxicol. Res. 2008; 24 (4): 253-261).

14. Parasuraman S, Raveendran R, Kesavan R. Blood sample collection in small laboratory animals. J Pharmacol Pharmacother. 2010; 1(2): 87-93. 
15. Suckow MA, Danneman P, Brayton C. The laboratory mouse. CRC Press LLC, USA, 2001.

16. Hanh T, Serog P, Fauconnier J. One-Year Effectiveness of a 3 Week Balneotherapy Program for the Treatment of Overweight or Obesity. Evidence-Based Complementary and Alternative Medicine. 2012; Article ID 150839.

17. Lange U, Muller-Ladner U, Schmidt KL. Balneotherapy in rheumatic diseases--an overview of novel and known aspects. Rheumatol Int. 2006; 26(6): 497-9.

18. Lu HC, Chang WT, Hsu CL. Inhibitory effect of deep sea water on adipogenesis in 3T3-L1 adipocytes. Chung Shan Med J. 2015; 26: 35-41.

19. Pagourelias ED, Zorou PG, Tsaligopoulos M, Athyros VG, et al. Carbon dioxide balneotherapy and cardiovascular disease. Int J Biometeorol. 2011; 55(5): 657-63.

20. Greco-Otto P, Bond S, Sides R, Kwong GPS, Bayly W. et al. Workload of horses on a water treadmill :effect of speed and water height on oxygen consumption and cardiorespiratory parameters. BMC Veterinary Research. 2017; 13: 360-369.

21. Agishi Y. Endocrine and metabolic aspects of balneotherapy. Biometeorology. 1985; 10(29):89103.

22. Agishi Y. Hot springs and the physiological functions of humans. Asian Med J. 1995; 38:115124.

23. Albertini MC, Teodori T, Accorsi A. Sulphurous mineral water oral therapy: Effects on erythrocyte metabolism. Food and Chemical Toxicology. 2008; 46(10): 3343-3350

24. Ejaz S, Nasim Fuh, Ashraf M. Hematological and Biochemical Profile of Patients Suffering from Non-Atopic Asthma. Insights Chest Dis. 2017; 2:110.

25. Fahy JV, Kim KW, Liu J, Boushey HA. Prominent neutrophilic inflammation in sputum from subjects with asthma exacerbation. J Allergy Clin Immunol. 1995; 95: 843-852.

26. Sukenik S, Abu-Shakra M, Flusser D. Balneotherapy in autoimmune diseases. Isr J Med Sci. 1997; 33(4): 258-61.

27. Apelgren KN, Rombeau JL, Twomey PL, Miller RA. Comparison of nutritional indices and outcome in critically ill patients. Crit Care Med. 1982; 10: 305-307.

28. Cantin AM, Paquette B, Richter M, Larivee P. Albuminmediated regulation of cellular glutathione and nuclear factor kappa B activation. Am J Respir Crit Care Med. 2000; 162: 1539-1546.

29. Misso Nl, Brooks-Wildhaber J, Ray S, Vally H, Thompson PJ. Plasma concentrations of dietary and nondietary antioxidants are low in severe asthma. Eur Respir J. 2005; 26: 257-264.

30. Huang HL, Ho SY, Li CH, Chu FY, Ciou LP. et al. Bronchial asthma is associated with increased risk of chronic kidney disease. BMC Pulm Med. 2014; 8;14:80.

31. Rascu A, Arghir OC, Naghi E, Otelea MR. Serum Aminotransferases and the Severity of Asthma. Rev.Chim. 2018; 69(5): 1200-1202.

32. Wu P, Dupont WD, Griffin MR, Carroll KN, Mitchel EF. et al. Evidence of a causal role of winter virus infection during infancy in early childhood asthma. Am J Respir Crit Care Med. 2008; 178(11):1123-9.

33. Perez-Granados AM, Navas-Carretero S, Schoppen S, Vaquero MP. Reduction in cardiovascular risk by sodium-bicarbonated mineral water in moderately hypercholesterolemic young adults. J Nutr Biochem. 2010; 21: 948-953.

34. Lee KS, Kwon YS, Kim S, Moon DS, Kim HJ. et al. Regulatory mechanism of mineral-balanced deep sea water on hypocholesterolemic effects in HepG2 hepatic cells. Biomed Pharmacother. 2017; 86: 405-413.

35. Faryadi Q. The magnificent effect of magnesium to human health: a critical review. International Journal of Applied Science and Technology. 2012; 2(3): 118-126.

36. Nani N, Majid FAA, Jaafar AB, Mahdzir A, Musa MN. Potential Health Benefits of Deep Sea Water: A Review. Evidence-Based Complementary and Alternative Medicine. 2016; Article ID 6520475.

37. Schoppen S, Pérez-Granados AM, Carbajal A, Sarriá B, Sánchez-Muniz FJ. et al. Sodium bicarbonated mineral water decreases postprandial lipaemia in postmenopausal women compared to a low mineral water. Br J Nutr. 2005; (4): 582-7.

38. Gülcan E, Bulut I, Toker A, Gülcan A. Evaluation of glucose tolerance status in patients with asthma bronchiale. J Asthma. 2009; 46(2):2079.

39. Calışkan, D. Afyonkarahisar bölgesi kaplıca sularının farelerde deneysel oluşturulan diabetes mellitus üzerine tedavi edici etkilerinin araștırılması. Yüksek Lisans Tezi. Afyon Kocatepe Üniversitesi, Afyonkarahisar, 2019. 
Table 1. Statistical comparison of body temperature, pulse and respiratory in the animals

\begin{tabular}{|c|c|c|c|c|}
\hline \multirow{2}{*}{\multicolumn{2}{|c|}{ Measurement Time/Parameters }} & \multirow{2}{*}{$\begin{array}{c}T \\
\left({ }^{\circ} \mathrm{C}\right) \\
X \pm S D \\
\end{array}$} & \multirow{3}{*}{$\begin{array}{c}\mathrm{P} \\
\text { (frequence/min) } \\
\mathrm{X} \pm \mathrm{SD} \\
\end{array}$} & \multirow{2}{*}{$\begin{array}{c}R \\
\text { (frequence/min) } \\
X \pm S D \\
\end{array}$} \\
\hline & & & & \\
\hline & Groups & & & \\
\hline BS $(n=40)$ & - & $37.00 \pm 0.10$ & $314.20 \pm 46.10^{f}$ & $118.34 \pm 36.40^{\mathrm{e}}$ \\
\hline $\operatorname{AAF}(n=36)$ & - & $37.30 \pm 0.10$ & $356.12 \pm 56.20^{\mathrm{e}}$ & $153.14 \pm 38.20^{b}$ \\
\hline \multirow{2}{*}{$\begin{array}{c}\text { AT } \\
\text { 1st Day }\end{array}$} & CG $(n=16)$ & $37.30 \pm 0.10$ & $351.18 \pm 53.00^{\mathrm{e}}$ & $133.12 \pm 36.40^{\text {cd }}$ \\
\hline & SG $(n=16)$ & $37.20 \pm 0.10$ & $367.42 \pm 55.20^{d}$ & $143.16 \pm 35.27^{b c}$ \\
\hline \multirow{2}{*}{$\begin{array}{c}\text { AT } \\
\text { 7th Day }\end{array}$} & CG $(n=12)$ & $37.30 \pm 0.10$ & $374.13 \pm 34.00^{\text {cd }}$ & $138.42 \pm 32.28^{c}$ \\
\hline & SG $(n=12)$ & $37.20 \pm 0.00$ & $465.14 \pm 36.40^{b}$ & $149.32 \pm 27.18^{b}$ \\
\hline \multirow{2}{*}{$\begin{array}{c}\text { AT } \\
\text { 14th Day }\end{array}$} & CG $(n=8)$ & $37.30 \pm 0.10$ & $389.35 \pm 32.14^{c}$ & $147.24 \pm 22.20^{b}$ \\
\hline & $S G(n=8)$ & $37.20 \pm 0.00$ & $478.26 \pm 24.12^{b}$ & $163.18 \pm 23.14^{\mathrm{a}}$ \\
\hline \multirow{2}{*}{$\begin{array}{c}\text { AT } \\
\text { 21th Day }\end{array}$} & CG $(n=4)$ & $37.20 \pm 0.10$ & $393.18 \pm 20.34^{c}$ & $151.28 \pm 19.10^{b}$ \\
\hline & $S G(n=4)$ & $37.10 \pm 0.10$ & $491.18 \pm 19.22^{\mathrm{a}}$ & $166.35 \pm 17.23^{\mathrm{a}}$ \\
\hline
\end{tabular}

a-h : Different letters in the same column are statistically significant $(\mathrm{p}<0.05)$. BS: Before study, AAF:

After asthma formation, AT: After treatment, CG: Control group, SG: Study group

Table 2. Hematological findings of the animals

\begin{tabular}{|c|c|c|c|c|c|c|c|}
\hline \multicolumn{2}{|c|}{$\begin{array}{c}\text { Measurement } \\
\text { Time/Parameters }\end{array}$} & $\begin{array}{c}\text { WBC } \\
\left(10^{3} / \mathbf{m m} 3\right)\end{array}$ & $\begin{array}{c}\text { RBC } \\
\left(10^{6} / \mathrm{mm} 3\right)\end{array}$ & $\underset{(\mathrm{g} / \mathrm{dl})}{\mathrm{HB}}$ & $\begin{array}{l}\text { HCT } \\
(\%)\end{array}$ & $\begin{array}{c}\text { PLT } \\
(103 / \mathrm{mm} 3)\end{array}$ & $\begin{array}{l}\text { MCV } \\
\text { (fl) }\end{array}$ \\
\hline & Groups & $\mathbf{X} \pm \mathbf{S D}$ & $\mathbf{X} \pm \mathbf{S D}$ & $\mathbf{X} \pm \mathbf{S D}$ & $\mathrm{X} \pm \mathrm{SD}$ & $\mathbf{X} \pm \mathbf{S D}$ & $\mathbf{X} \pm \mathbf{S D}$ \\
\hline BS $(n=40)$ & - & $8.42 \pm 2.10^{\mathrm{e}}$ & $8.06 \pm 2.23^{\mathrm{bc}}$ & $12.98 \pm 2.44^{\mathrm{b}}$ & $44.04 \pm 2.13^{\mathrm{a}}$ & $292.23 \pm 43.14^{\mathrm{a}}$ & $54.62 \pm 214$ \\
\hline AAF $(n=36)$ & - & $15.34 \pm 3.18^{\mathrm{a}}$ & $6.27 \pm 3.18^{\mathrm{d}}$ & $15.28 \pm 3.12^{\mathrm{a}}$ & $33.03 \pm 3.12^{\mathrm{ef}}$ & $1141.32 \pm 41.16^{\mathrm{e}}$ & $53.18 \pm 3.26^{\mathrm{a}}$ \\
\hline \multirow{2}{*}{$\begin{array}{c}\text { AT } \\
\text { 1st Day } \\
\end{array}$} & CG $(n=16)$ & $15.46 \pm 3.20^{\mathrm{a}}$ & $6.68 \pm 2.18^{\mathrm{d}}$ & $13.76 \pm 2.18^{\mathrm{b}}$ & $33.46 \pm 3.24^{\mathrm{f}}$ & $162.27 \pm 38.13^{\mathrm{e}}$ & $50.11 \pm 3.17^{\mathrm{b}}$ \\
\hline & $\mathrm{SG}(\mathrm{n}=16)$ & $15.04 \pm 3.10^{\mathrm{a}}$ & $6.96 \pm 2.32^{\mathrm{d}}$ & $13.65 \pm 2.07^{b}$ & $34.08 \pm 3.43^{\text {ef }}$ & $176.27 \pm 37.23^{\mathrm{de}}$ & $48.96 \pm 3.18$ \\
\hline \multirow{2}{*}{$\begin{array}{c}\text { AT } \\
\text { 7th Day }\end{array}$} & $\mathrm{CG}(\mathrm{n}=12)$ & $14.38 \pm 2.26^{\mathrm{b}}$ & $7.04 \pm 1.48^{\mathrm{c}}$ & $8.98 \pm 2.34^{\mathrm{d}}$ & $35.37 \pm 2.18^{\mathrm{e}}$ & $178.43 \pm 33.14^{\mathrm{e}}$ & $50.18 \pm 2.32^{\mathrm{c}}$ \\
\hline & $\mathrm{SG}(\mathrm{n}=12)$ & $13.28 \pm 2.20^{\mathrm{c}}$ & $8.86 \pm 1.32^{\mathrm{ab}}$ & $10.94 \pm 2.26^{\mathrm{c}}$ & $39.28 \pm 2.17^{\mathrm{c}}$ & $203.21 \pm 31.17^{\mathrm{c}}$ & $44.46 \pm 2.17^{\mathrm{e}}$ \\
\hline \multirow{2}{*}{$\begin{array}{c}\text { AT } \\
\text { 14th Day }\end{array}$} & $\mathrm{CG}(\mathrm{n}=8)$ & $13.05 \pm 2.34^{\mathrm{c}}$ & $7.78 \pm 1.14^{\mathrm{c}}$ & $9.84 \pm 1.54^{\mathrm{cd}}$ & $37.21 \pm 1.24^{\mathrm{e}}$ & $204.13 \pm 25.03^{\mathrm{de}}$ & $47.91 \pm 2.14^{\mathrm{d}}$ \\
\hline & SG $(n=8)$ & $11.39 \pm 1.23^{\mathrm{d}}$ & $9.03 \pm 1.13^{\mathrm{a}}$ & $10.86 \pm 1.34^{\mathrm{c}}$ & $41.13 \pm 1.16^{\mathrm{b}}$ & $256.22 \pm 23.13^{\mathrm{b}}$ & $45.61 \pm 2.08^{f}$ \\
\hline \multirow{2}{*}{$\begin{array}{c}\text { AT } \\
\text { 21th Day }\end{array}$} & CG $(n=4)$ & $11.06 \pm 1.12^{\mathrm{d}}$ & $8.44 \pm 0.46^{\mathrm{b}}$ & $10.78 \pm 0.32^{\mathrm{c}}$ & $38.23 \pm 0.44^{\mathrm{d}}$ & $225.18 \pm 18.16^{\mathrm{d}}$ & $45.49 \pm 1.34^{\mathrm{d}}$ \\
\hline & $\mathrm{SG}(\mathrm{n}=4)$ & $8.05 \pm 1.14^{\mathrm{e}}$ & $9.48 \pm 0.34^{\mathrm{a}}$ & $13.01 \pm 0.27^{\mathrm{b}}$ & $45.16 \pm 0.23^{\mathrm{a}}$ & $295.12 \pm 15.32^{\mathrm{a}}$ & $47.79 \pm 1.22^{\mathrm{g}}$ \\
\hline
\end{tabular}

\section{Continue Table 2}

\begin{tabular}{|c|c|c|c|c|c|c|c|c|}
\hline \multicolumn{2}{|c|}{$\begin{array}{c}\text { Measurement } \\
\text { Time/Parameters }\end{array}$} & \multirow{2}{*}{$\begin{array}{c}\begin{array}{c}\text { MCH } \\
\text { (pg) }\end{array} \\
\mathrm{X} \pm \text { SD }\end{array}$} & \multirow{2}{*}{$\begin{array}{c}\begin{array}{c}\mathrm{MCHC} \\
(\mathrm{g} / \mathrm{dl})\end{array} \\
\mathrm{X} \pm \mathrm{SD}\end{array}$} & \multirow{2}{*}{$\begin{array}{c}\text { LENF } \\
\% \\
\mathrm{X} \pm \text { SD }\end{array}$} & \multirow{2}{*}{$\begin{array}{c}\begin{array}{c}\text { NOTR } \\
\%\end{array} \\
\mathrm{X} \pm \text { SD }\end{array}$} & \multirow{2}{*}{$\begin{array}{c}\begin{array}{c}\text { EOS } \\
\%\end{array} \\
\mathrm{X} \pm \mathrm{SD}\end{array}$} & \multirow{2}{*}{$\begin{array}{c}\text { MON } \\
\% \\
\mathbf{X} \pm \text { SD }\end{array}$} & \multirow{2}{*}{$\begin{array}{c}\begin{array}{c}\text { BAS } \\
\%\end{array} \\
\mathrm{X} \pm \mathrm{SD}\end{array}$} \\
\hline & Groups & & & & & & & \\
\hline BS $(n=40)$ & - & $16.17 \pm 4.21^{\mathrm{c}}$ & $29.58 \pm 3.47^{b}$ & $62.18 \pm 4.40^{\mathrm{a}}$ & $33.20 \pm 3.10^{\mathrm{d}}$ & $2.20 \pm 1.10^{\mathrm{f}}$ & $3.30 \pm 0.40^{\mathrm{c}}$ & 0.00 \\
\hline $\mathbf{A A F}(n=36)$ & - & $22.28 \pm 5.24^{\mathrm{a}}$ & $45.56 \pm 3.58^{a}$ & $44.44 \pm 6.23^{\mathrm{g}}$ & $42.14 \pm 5.04^{\mathrm{a}}$ & $7.48 \pm 3.20^{\mathrm{a}}$ & $5.40 \pm 2.20^{\mathrm{a}}$ & $2.30 \pm 0.20^{\mathrm{a}}$ \\
\hline \multirow{2}{*}{$\begin{array}{c}\text { AT } \\
\text { 1st Day }\end{array}$} & $\mathrm{CG}(\mathrm{n}=16)$ & $20.54 \pm 4.08^{b}$ & $45.03 \pm 3.18^{\mathrm{a}}$ & $44.68 \pm 6.10^{\mathrm{g}}$ & $42.64 \pm 5.03^{\mathrm{a}}$ & $7.84 \pm 3.00^{\mathrm{a}}$ & $5.34 \pm 1.18^{\mathrm{a}}$ & $2.30 \pm 0.30^{\mathrm{a}}$ \\
\hline & $\mathrm{SG}(\mathrm{n}=16)$ & $20.22 \pm 4.13^{b}$ & $28.43 \pm 3.09^{b}$ & $44.63 \pm 5.3^{\mathrm{g}}$ & $42.18 \pm 4.43^{\mathrm{a}}$ & $7.18 \pm 3.14^{\mathrm{a}}$ & $5.03 \pm 1.17^{\mathrm{a}}$ & $2.20 \pm 0.20^{\mathrm{a}}$ \\
\hline \multirow{2}{*}{$\begin{array}{c}\text { AT } \\
\text { 7th Day }\end{array}$} & $\mathrm{CG}(\mathrm{n}=12)$ & $12.75 \pm 2.36^{\mathrm{d}}$ & $25.39 \pm 2.43^{\mathrm{d}}$ & $46.36 \pm 3.24^{f}$ & $41.20 \pm 3.10^{\mathrm{a}}$ & $6.23 \pm 2.16^{\mathrm{b}}$ & $5.12 \pm 1.05^{\mathrm{a}}$ & $2.30 \pm 0.10^{\mathrm{a}}$ \\
\hline & $\mathrm{SG}(\mathrm{n}=12)$ & $12.35 \pm 2.44^{\mathrm{d}}$ & $27.68 \pm 2.37^{b c}$ & $52.32 \pm 3.12^{\mathrm{d}}$ & $41.18 \pm 3.00^{\mathrm{a}}$ & $3.20 \pm 1.30^{\mathrm{d}}$ & $4.22 \pm 1.08^{\mathrm{b}}$ & $1.50 \pm 0.10^{\mathrm{b}}$ \\
\hline \multirow{2}{*}{$\begin{array}{c}\text { AT } \\
\text { 14th Day }\end{array}$} & $\mathrm{CG}(\mathrm{n}=8)$ & $12.59 \pm 1.56^{\mathrm{d}}$ & $26.57 \pm 1.38^{\mathrm{c}}$ & $50.13 \pm 2.22^{\mathrm{e}}$ & $40.16 \pm 2.20^{\mathrm{b}}$ & $4.44 \pm 1.04^{\mathrm{c}}$ & $4.43 \pm 0.40^{\mathrm{b}}$ & $2.00 \pm 0.10^{\mathrm{ab}}$ \\
\hline & $\mathrm{SG}(\mathrm{n}=8)$ & $12.12 \pm 1.41^{\mathrm{d}}$ & $26.38 \pm 1.29^{c}$ & $57.23 \pm 2.14^{\mathrm{b}}$ & $35.16 \pm 2.10^{\mathrm{cd}}$ & $2.23 \pm 1.00^{\mathrm{d}}$ & $2.04 \pm 0.38^{c}$ & $1.00 \pm 0.10^{\mathrm{c}}$ \\
\hline \multirow{2}{*}{$\begin{array}{c}\text { AT } \\
\text { 21th Day }\end{array}$} & $\mathrm{CG}(\mathrm{n}=4)$ & $12.86 \pm 0.64^{\mathrm{d}}$ & $28.25 \pm 0.68^{b}$ & $54.08 \pm 1.43^{\mathrm{c}}$ & $37.20 \pm 1.20^{\mathrm{c}}$ & $5.03 \pm 0.44^{\mathrm{cd}}$ & $3.12 \pm 0.20^{\mathrm{b}}$ & $1.10 \pm 0.20^{\mathrm{c}}$ \\
\hline & $\mathrm{SG}(\mathrm{n}=4)$ & $13.86 \pm 0.58^{d}$ & $28.93 \pm 0.57^{b}$ & $61.25 \pm 1.38^{\mathrm{a}}$ & $34.18 \pm 1.10^{\mathrm{d}}$ & $1.03 \pm 0.16^{\mathrm{e}}$ & $2.73 \pm 0.10^{\mathrm{d}}$ & $0.30 \pm 0.20^{\mathrm{d}}$ \\
\hline
\end{tabular}

a-g: Different letters in the same column are statistically significant $(\mathrm{p}<0.05)$. BS: Before study, AAF: After asthma formation, AT: After treatment, CG: Control group, SG: Study group 
Table 3. Blood biochemical findings of the animals

\begin{tabular}{|c|c|c|c|c|c|c|c|}
\hline \multicolumn{2}{|c|}{$\begin{array}{c}\text { Measurement } \\
\text { Time/Parameters }\end{array}$} & \multirow{2}{*}{$\begin{array}{c}\begin{array}{c}\text { AST } \\
\text { (IU/L) }\end{array} \\
\mathbf{X} \pm \text { SD }\end{array}$} & \multirow{2}{*}{$\begin{array}{c}\begin{array}{c}\text { ALP } \\
\text { (IU/L) }\end{array} \\
\mathbf{X} \pm \text { SD }\end{array}$} & \multirow{2}{*}{$\begin{array}{c}\begin{array}{c}\text { GGT } \\
\text { (IU/L) }\end{array} \\
\mathbf{X} \pm \text { SD }\end{array}$} & \multirow{2}{*}{$\begin{array}{c}\begin{array}{c}\text { LDH } \\
\text { (IU/L) }\end{array} \\
\mathbf{X} \pm \text { SD }\end{array}$} & \multirow{2}{*}{$\begin{array}{c}\begin{array}{c}\text { TP } \\
(\mathrm{g} / \mathrm{dl})\end{array} \\
\mathbf{X} \pm \mathbf{S D}\end{array}$} & \multirow{2}{*}{$\begin{array}{c}\begin{array}{c}\text { ALB } \\
\text { (g/dl) }\end{array} \\
\mathbf{X} \pm \text { SD }\end{array}$} \\
\hline & Groups & & & & & & \\
\hline BS $(n=40)$ & - & $96.17 \pm 12.43^{\mathrm{e}}$ & $78.86 \pm 9.40^{\mathrm{d}}$ & $3.57 \pm 1.04^{\mathrm{d}}$ & $278.44 \pm 36.18^{\mathrm{e}}$ & $56.29 \pm 6.32^{\mathrm{b}}$ & $34.09 \pm 3.38^{\mathrm{a}}$ \\
\hline $\mathbf{A A F}(n=36$ & - & $217.56 \pm 44.18^{\mathrm{a}}$ & $186.48 \pm 38.34^{\mathrm{a}}$ & $6.47 \pm 3.25^{\mathrm{a}}$ & $383.44 \pm 54.42^{\mathrm{a}}$ & $58.44 \pm 7.48^{\mathrm{a}}$ & $21.34 \pm 2.18^{\mathrm{e}}$ \\
\hline \multirow{2}{*}{$\begin{array}{c}\text { AT } \\
\text { 1st Day }\end{array}$} & $\mathrm{CG}(\mathrm{n}=16)$ & $212.14 \pm 32.48^{\mathrm{a}}$ & $184.43 \pm 40.12^{\mathrm{a}}$ & $6.44 \pm 2.18^{\mathrm{a}}$ & $385.13 \pm 47.46^{\mathrm{a}}$ & $57.26 \pm 5.23^{\mathrm{ab}}$ & $21.24 \pm 2.16^{\mathrm{e}}$ \\
\hline & $\mathrm{SG}(\mathrm{n}=16)$ & $203.13 \pm 28.34^{\mathrm{a}}$ & $181.28 \pm 38.17^{\mathrm{a}}$ & $6.13 \pm 2.14^{\mathrm{a}}$ & $374.27 \pm 45.41^{\mathrm{a}}$ & $56.73 \pm 6.18^{b}$ & $21.67 \pm 2.23^{\mathrm{e}}$ \\
\hline \multirow{2}{*}{$\begin{array}{c}\text { AT } \\
\text { 7th Day }\end{array}$} & $\mathrm{CG}(\mathrm{n}=12)$ & $197.36 \pm 24.21^{\mathrm{b}}$ & $158.24 \pm 26.35^{\mathrm{b}}$ & $6.01 \pm 1.54^{\mathrm{a}}$ & $353.28 \pm 32.14^{b}$ & $58.01 \pm 3.24^{\mathrm{a}}$ & $22.45 \pm 1.18^{\mathrm{e}}$ \\
\hline & $\mathrm{SG}(\mathrm{n}=12)$ & $153.04 \pm 18.46^{\mathrm{d}}$ & $114.45 \pm 21.23$ & $5.48 \pm 1.47^{\mathrm{b}}$ & $324.16 \pm 31.13^{\mathrm{c}}$ & $57.21 \pm 3.45^{\mathrm{ab}}$ & $25.37 \pm 1.26^{\mathrm{d}}$ \\
\hline \multirow{2}{*}{$\begin{array}{c}\text { AT } \\
\text { 14th Day }\end{array}$} & $\mathrm{CG}(\mathrm{n}=8)$ & $178.43 \pm 15.34^{\mathrm{c}}$ & $123.56 \pm 12.24^{\mathrm{c}}$ & $5.48 \pm 0.56^{\mathrm{b}}$ & $333.18 \pm 18.17^{\mathrm{c}}$ & $56.64 \pm 3.33^{\mathrm{b}}$ & $24.31 \pm 1.14^{\mathrm{d}}$ \\
\hline & $\mathrm{SG}(\mathrm{n}=8)$ & $119.42 \pm 9.34^{\mathrm{f}}$ & $86.88 \pm 7.23^{\mathrm{d}}$ & $4.18 \pm 0.38^{c}$ & $299.16 \pm 15.23^{d}$ & $57.21 \pm 3.27^{\mathrm{ab}}$ & $32.14 \pm 1.12^{b}$ \\
\hline \multirow{2}{*}{$\begin{array}{c}\text { AT } \\
\text { 21th Day }\end{array}$} & $\mathrm{CG}(\mathrm{n}=4)$ & $153.64 \pm 6.12^{\mathrm{d}}$ & $117.45 \pm 5.32^{\mathrm{c}}$ & $4.14 \pm 0.25^{\mathrm{c}}$ & $303.08 \pm 7.24^{\mathrm{d}}$ & $57.34 \pm 1.28^{\mathrm{ab}}$ & $27.13 \pm 0.54^{\mathrm{c}}$ \\
\hline & $\mathrm{SG}(\mathrm{n}=4)$ & $88.48 \pm 4.09^{\mathrm{e}}$ & $77.65 \pm 4.13^{\mathrm{d}}$ & $3.43 \pm 0.18^{\mathrm{d}}$ & $274.13 \pm 6.22^{\mathrm{e}}$ & $56.69 \pm 1.37^{b}$ & $35.01 \pm 0.46^{\mathrm{a}}$ \\
\hline
\end{tabular}

\section{Continue Table 3}

\begin{tabular}{|c|c|c|c|c|c|c|}
\hline \multicolumn{2}{|c|}{$\begin{array}{c}\text { Measurement } \\
\text { Time/Parameters }\end{array}$} & $\begin{array}{l}\text { GLU } \\
(\mathrm{g} / \mathrm{dl})\end{array}$ & $\begin{array}{l}\text { TCHOL } \\
(\mathrm{mg} / \mathrm{dL})\end{array}$ & $\begin{array}{l}\text { CREA } \\
(\mathrm{mg} / \mathrm{dl})\end{array}$ & $\begin{array}{c}\text { BUN } \\
(\mathrm{mg} / \mathrm{dl})\end{array}$ & $\begin{array}{c}\mathbf{I g E} \\
\mathrm{ng} / \mathrm{ml}\end{array}$ \\
\hline & Groups & $\mathbf{X} \pm \mathbf{S D}$ & $\mathrm{X} \pm \mathrm{SD}$ & $\mathrm{X} \pm \mathrm{SD}$ & $\mathbf{X} \pm \mathbf{S D}$ & $\mathbf{X} \pm$ SD \\
\hline BS $(n=40)$ & - & $1.59 \pm 0.31^{\mathrm{b}}$ & $90.24 \pm 8.07^{f}$ & $0.61 \pm 0.16^{\mathrm{c}}$ & $25.43 \pm 3.54$ & $20.24 \pm 2.45$ \\
\hline $\mathbf{A A F}(\mathrm{n}=36)$ & & $2.78 \pm 0.42^{\mathrm{a}}$ & $126.27 \pm 23.32^{\mathrm{a}}$ & $0.86 \pm 0.18^{\mathrm{a}}$ & $48.54 \pm 6.14$ & $60.38 \pm 7.451$ \\
\hline \multirow{2}{*}{$\begin{array}{c}\text { AT } \\
\text { 1st Day }\end{array}$} & $\mathrm{CG}(\mathrm{n}=16)$ & $1.83 \pm 038^{\mathrm{b}}$ & $124.18 \pm 21.22^{\mathrm{a}}$ & $0.85 \pm 0.17^{\mathrm{a}}$ & $48.05 \pm 5.66$ & $59.48 \pm 6.17$ \\
\hline & $S G(n=16)$ & $1.88 \pm 0.34^{\mathrm{b}}$ & $123.14 \pm 22.04^{\mathrm{a}}$ & $0.63 \pm 0.19^{\mathrm{bc}}$ & $43.41 \pm 4.34$ & $58.19 \pm 5.32$ \\
\hline \multirow{2}{*}{$\begin{array}{c}\text { AT } \\
\text { 7th Day }\end{array}$} & $C G(n=12)$ & $0.93 \pm 0.23^{\mathrm{d}}$ & $116.23 \pm 13.12^{c}$ & $0.78 \pm 0.13^{\mathrm{ab}}$ & $39.02 \pm 2.25$ & $44.13 \pm 3.21$ \\
\hline & $\mathrm{SG}(\mathrm{n}=12)$ & $1.26 \pm 0.25^{\mathrm{c}}$ & $105.67 \pm 12.48^{\mathrm{d}}$ & $0.67 \pm 0.11$ & $30.43 \pm 1.26$ & $35.18 \pm 2.39$ \\
\hline \multirow{2}{*}{$\begin{array}{c}\text { AT } \\
\text { 14th Day }\end{array}$} & $\mathrm{CG}(\mathrm{n}=8)$ & $1.04 \pm 0.13^{\mathrm{c}}$ & $108.27 \pm 9.18^{\mathrm{d}}$ & $0.72 \pm 0.09^{\mathrm{b}}$ & $32.25 \pm 1.12$ & $37.18 \pm 2.31$ \\
\hline & $\mathrm{SG}(\mathrm{n}=8)$ & $1.54 \pm 0.10^{\mathrm{b}}$ & $95.68 \pm 8.13^{\mathrm{ef}}$ & $0.59 \pm 0.08^{c}$ & $27.13 \pm 1.11$ & $27.20 \pm 1.32$ \\
\hline \multirow{2}{*}{$\begin{array}{c}\text { AT } \\
\text { 21th Day }\end{array}$} & $\mathrm{CG}(\mathrm{n}=4)$ & $1.17 \pm 0.06^{\mathrm{cd}}$ & $101.43 \pm 6.32^{\mathrm{e}}$ & $0.65 \pm 0.05^{\mathrm{bc}}$ & $29.28 \pm 0.43$ & $34.16 \pm 0.68$ \\
\hline & $\mathrm{SG}(\mathrm{n}=4)$ & $1.62 \pm 0.04^{b}$ & $89.23 \pm 3.18^{f}$ & $0.57 \pm 0.03^{c}$ & $24.18 \pm 0.38$ & $21.03 \pm 0.57$ \\
\hline
\end{tabular}

a-f: Different letters in the same column are statistically significant $(\mathrm{p}<0.05)$. BS: Before study, AAF: After asthma formation, AT: After treatment, CG: Control group, SG: Study group 